\title{
Resveratrol reduces chronic inflammation and improves insulin action in the myocardium of high-fat diet-induced obese rats
}

\author{
Resveratrol reduz a inflamação crônica e melhora \\ a ação da insulina em miocárdio de ratos com \\ obesidade induzida por dieta hiperlipídica
}

Thaís Fernandes LUCIANO'

Schérolin de Oliveira MARQUES ${ }^{1}$

Bruno Luiz da Silva PIERI ${ }^{1}$

Daniela Roxo de SOUZA'

Fabio Santos de LIRA ${ }^{2}$

Cláudio Teodoro de SOUZA

A B S T R A C T

\section{Objective}

To evaluate the effects of resveratrol on insulin signaling and inflammation pathway in the myocardium of high-fat diet-induced obese rats.

\section{Methods}

Thirty Wistar rats were divided into a control group ( $n=10$, standard diet), obese group ( $n=10$, high-fat diet), and obese supplemented with resveratrol group $(n=10,20 \mathrm{mg} / \mathrm{kg} /$ day) for eight weeks. An insulin tolerance test was performed at the end of the study period " 0 " (without insulin), 5, 10, 15, 20, 25, and 30 minutes after an intraperitoneal injection of insulin $(2 \mathrm{U} / \mathrm{kg}$ ). Body and epididymal adipose tissue were weighed. Fragments of the myocardium were extracted for Western blot analyses of insulin pathway and proinflammatory molecules.

\section{Results}

Resveratrol increased the rate of glucose disappearance, phosphorylation of the insulin receptor, insulin receptor substrate 1, and protein kinase $\mathrm{B}$; and reduced expression of tumor necrosis factor alpha and of the molecules

1 Universidade do Extremo Sul Catarinense, Unidade Acadêmica de Ciências da Saúde, Programa de Pós-Graduação em Ciências da Saúde. Av. Universitária, Bairro Universitário, 88806-000, Criciúma, SC, Brasil. Correspondência para/Correspondence to: CT SOUZA.E-mail: <ctsouza@unesc.net>.

2 Universidade Estadual de São Paulo, Departamento de Educação Física, Grupo de Pesquisa em Imunometabolismo. São Paulo, SP, Brasil.

Support: Conselho Nacional de Desenvolvimento Científico and Tecnológico, Fundação de Amparo à Pesquisa do Estado de Santa Catarina, and Universidade do Extremo Sul Catarinense. 
involved in proinflammatory signal transduction, namely lkappa B kinase and nuclear factor kappa B complex. The results also suggest that higher insulin sensitivity and lower levels of proinflammatory molecules occurred regardless of weight and epididymal adipose tissue loss.

\section{Conclusion}

Resveratrol increases insulin action and reduces inflammatory molecules in the myocardium.

Indexing terms: Obesity. Resveratrol. Insulin resistance. Inflammation.

\section{RE S U M O}

\section{Objetivo}

Avaliar o efeito do resveratrol sobre a via de sinalização da insulina e melhora do quadro inflamatório no miocárdio de ratos Wistar obesos induzidos por dieta.

\section{Métodos}

Ratos Wistar foram divididos em grupos: controle (dieta padrão para roedores), obeso (dieta hiperlipídica) e obeso suplementado com resveratrol $(20 \mathrm{mg} / \mathrm{kg} / \mathrm{dia})$, por 8 semanas $(n=10)$. Ao final do período experimental, realizou-se o teste de tolerância à insulina, nos tempos 0 (sem insulina), 5, 10, 15, 20, 25 e 30 minutos após injeção intraperitoneal de insulina (2 U/kg). O peso corporal e o tecido adiposo epididimal foram mensurados. Fragmentos do miocárdio foram extraídos para análises da via da insulina e moléculas pró-inflamatórias através de Western blot.

\section{Resultados}

Os resultados indicam que a intervenção com resveratrol aumenta a constante de decaimento da glicose, fosforilação do receptor de insulina, substrato do receptor de insulina e da proteína quinase $B$. A suplementação de resveratrol também reduziu os níveis proteicos do fator de necrose tumoral alfa e de moléculas envolvidas com a transdução do sinal pró-inflamatório (quinase indutora do kappa B e fator nuclear kappa B). Os resultados ainda sugerem que a melhora na sensibilidade à insulina e a redução das moléculas pró-inflamatórias ocorreram independentemente da perda de peso corporal e da redução do tecido adiposo epididimal.

\section{Conclusão}

A suplementação de resveratrol aumenta a sensibilidade à insulina, o que está relacionado à redução de fatores inflamatórios no miocárdio.

Termos de indexação: Obesidade. Resveratrol. Resistência à insulina. Inflamação.

\section{N TROD UCTION}

The rapid increase in the prevalence of obesity shows that environmental changes, such as inappropriate eating patterns and little physical activity, are determinants in the increase of the global obesity epidemic ${ }^{1}$. Obesity is a decisive risk factor for diseases such as diabetes Mellitus type 2, high blood pressure, and cardiovascular diseases ${ }^{2,3}$. Morbidly obese patients are at greater risk of sudden death and cardiac problems ${ }^{4}$. A change in insulin sensitivity is an important link between these diseases. Insulin resistance occurs in the heart of obese rats, leading to a reduction in the amount and translocation of the protein
Glucose Transporter type 4 (GLUT4) to the sarcolemma ${ }^{5}$. Although the mechanisms that lead to insulin resistance have been widely studied in skeletal muscle, more studies on the cardiac tissue are necessary, along with possible pharmacological or non-pharmacological therapies.

Insulin is an anabolic hormone secreted by the pancreas in response to an increase in blood glucose ${ }^{6}$. Insulin action begins with insulin binding to a specific membrane receptor, called Insulin Receptor (IR) ${ }^{7}$. IR activation promotes tyrosine phosphorylation in various substrates, including Insulin Receptor 1 (IRS-1) and $2\left(\right.$ IRS-2) ${ }^{8}$. Phosphorylation of the IRS proteins exposes binding sites for another cytosolic protein called 
Phosphatidylinositol 3-Kinase (PI3-K), activating it 9,10 . Phosphatidylinositol 3-Kinase activation increases serine phosphorylation of the protein kinase B (Akt). The Akt protein is a serine/ threonine-specific protein kinase expressed in muscle tissue ${ }^{11}$. Through phosphorylation, the Akt protein is capable of activating many metabolic effects, such as glucose uptake as well as glycogen and protein synthesis.

Many molecules or molecular pathways of intracellular signal transduction can interfere with the insulin transduction pathway, possibly leading to insulin resistance. Of these, the literature mentions the importance of proinflammatory cytokines for the development of insulin resistance, especially IKappa B Kinase (IKK)/Nuclear Factor Kappa B (NF-KB) transcription factor pathway and Tumor Necrosis Factor alpha $(\mathrm{TNF} \alpha)^{12}$.

Some nutrients increase insulin action significantly ${ }^{13,14}$, such as resveratrol $\left(3,5,4^{\prime}\right.$ trihydroxystilbene), a phytoalexin found in plants and some foods, including peanuts, mulberries, and grapes ${ }^{15}$. Resveratrol provides cardiovascular protection ${ }^{16}$, inhibits platelet aggregation ${ }^{17}$, reduces inflammatory factors ${ }^{18}$, and improves glucose homeostasis ${ }^{19}$. The effects of resveratrol supplementation were investigated in insulinresistant ${ }^{20}$, high-fat diet-induced obese rats ${ }^{21}$, and found to improve glucose homeostasis and wholebody insulin sensitivity. However, neither the proinflammatory pathway nor the myocardium was assessed. Hence, the present study assessed whether resveratrol supplementation reduces inflammation and improves the insulin signal transduction pathway in the myocardium of obese rats.

\section{METHODS}

\section{Characterization of the animals and diet}

Thirty four-week-old male Wistar rats weighing approximately $115 \mathrm{~g}$ were obtained from the Universidade do Extremo Sul Catarinense
(Unesc) Laboratory Animal Facility. They were kept in 12/12-hour light/dark cycle at a temperature of $20^{\circ} \mathrm{C}$ to $22^{\circ} \mathrm{C}$. After one week of adaptation to the new environment, the animals were first divided into two groups: a lean group fed with standard rodent chow (Nuvital Nutrientes S.A., Colombo, PR, Brazil) (carbohydrates: 70.0\%; proteins: $20.0 \%$; fats $10.0 \%$, totaling $3.8 \mathrm{kcal} / \mathrm{g}$ ) $(n=10)$ called control group; and a group fed a high-fat diet (carbohydrates: $38.5 \%$; proteins: $15.0 \%$; fats $46.5 \%$, totaling $5.4 \mathrm{kcal} / \mathrm{g})(\mathrm{n}=20)$ for eight weeks. Both groups were given water daily. Once the animals became obese, they were submitted to the Intraperitoneal Insulin Tolerance Test (ITT) to verify their insulin resistance. The obese animals were then subdivided randomly into two groups: high-fat diet-induced obese rats (obese, $n=10$ ) and obese rats receiving resveratrol supplementation (obese+resv, $\mathrm{n}=10$ ).

All experiments were compliant with the principles and procedures established by the Colégio Brasileiro de Experimentação Animal (COBEA, Brazilian College of Animal Experimentation) and approved by Unesc's Research Ethics Committee under Protocol number 20/ 2011.

\section{Resveratrol Supplementation Protocol}

The supplemented animals received $20 \mathrm{mg} / \mathrm{kg}$ of resveratrol by gavage once a day for eight weeks. Resveratrol 100\% pure was purchased from the company Pharma Nostra Ltda (Rio de Janeiro, Brazil).

\section{Intraperitoneal insulin tolerance test}

The test was performed at the end of the experimental period. Food was removed six hours before the test and the first blood collection corresponded to time " 0 " Next, insulin $(2 \mathrm{U} / \mathrm{kg}$ of body weight) was injected intraperitoneally and blood samples were collected from a tail incision after 5, 10, 15, 20, 25, and 30 minutes to measure 
blood glucose. The constant of glucose disappearance during insulin tolerance test $\left(k_{\text {IIT }}\right)$ was given by the formula $0.693 / t_{1 / 2}$. The $t_{1 / 2}$ of glucose was given by Least Squares Analysis of the blood glucose level during the linear glucose disappearance phase.

\section{Epididymal fat weight}

The animals were sacrificed and the epididymal adipose tissue was removed and weighed by an analytical balance (Bel Engineering Ltda, Piracicaba, SP) with an accuracy of $0.001 \mathrm{~g}$ for comparing the groups. Body fat weight was expressed as a percentage of the body weight.

\section{Tissue extraction and Western Blot}

Twenty-four hours after the last supplementation, the rats were anesthetized with ketamine (50 mg/kg, Syntec; Cotia, SP) and xylazine (20 mg/kg, Syntec; Cotia, SP). Next, the abdominal cavity was opened and either saline (group without insulin (-), $0.1 \mathrm{~mL}$ ) or regular insulin (group with insulin (+), $0.1 \mathrm{~mL}, 10^{-6}$ ) was injected into the inferior vena cava. After the insulin (Humulin R; Eli Lilly, São Paulo, SP) injection, fragments of the myocardium were collected and immediately placed in a specific extraction buffer (1\% Triton-X 100, 100 mM Tris, pH 7.4 containing $100 \mathrm{mM}$ of sodium pyrophosphate, $100 \mathrm{mM}$ of sodium fluoride, $10 \mathrm{mM}$ of Ethylenediaminetetraacetic Acid (EDTA), $10 \mathrm{mM}$ of sodium vanadate, 2 mM of Phenylmethanesulfonylfluoride (PMSF), and $0.1 \mathrm{mg}$ of aprotinin/mL) and homogenized by a Polytron ${ }^{\circledast}$ homogenizer (Polytron MR 2100, Kinematica, Switzerland). At the end of the extraction, the animals were sacrificed by guillotine decapitation. Triton X-100 was added to all samples, which were then kept in ice for 40 minutes. The homogenized samples were centrifuged at $11000 \mathrm{rpm}$ for 30 minutes by the centrifuge Eppendorf 5804R (Eppendorf AG, Hamburg, Germany). The Bradford method determined the protein concentration on the supernatant. The proteins were then denatured by boiling at $100{ }^{\circ} \mathrm{C}$ in a Laemmli buffer system containing $100 \mathrm{mM}$ of Dithiothreitol (DDT).

Once the protein concentration was determined, the samples were loaded in Sodium Dodecyl Sulfate - Polyacrylamide Gel (SDS-Page) and separated by electrophoresis. The proteins separated by SDS-PAGE were transferred to a nitrocellulose membrane in the device Mini Trans-Blot ${ }^{\circledR}$ Electrophoretic Transfer Cell (BIO-RAD, Hercules, United States) and immediately blocked by a blocking buffer ( $5 \%$ albumin; $10 \mathrm{mmol} / \mathrm{L}$ of Tris; $150 \mathrm{mmol} / \mathrm{L}$ of $\mathrm{NaCl} ; 0.02 \%$ Tween 20) for two hours to minimize binding between the antibodies and nonspecific proteins. The membrane was incubated for 12 hours with the primary antibodies anti-pIR Tir1162/1163 and antipIRS1 ${ }^{\text {Tirg71 }}$ acquired from Cell Signaling Technology (Beverly, MA, United States) and anti-pAkt ${ }^{\text {Ser473, }}$ anti-TNF $\alpha$, anti-plKK $\alpha$, anti-NF- $\mathrm{KB}$, and $\beta$-actin acquired from Santa Cruz Biotechnology (Santa Cruz, CA, United States). After the primary antibody incubation, the membranes were rinsed again with a basal solution for three 5-minute sessions and incubated with the secondary antibody conjugated to peroxidase for chemiluminescence (Thermo Scientific, Rockford, IL, United States). Band intensity and area were determined by reading the autoradiographs developed by densitometry using a scanner ( $\mathrm{HP}^{\circledR}$ G2710) and the software Scion Image (Scion Corporation $^{\circledR}$ ).

\section{Statistical analysis}

The results were expressed as means \pm Standard Error of the Mean (SEM) and analyzed by one-way Analysis of Variance (Anova) followed by the Bonferroni post hoc test. The significance level was set at $5 \%(p<0.05)$. The software Statistical Package for the Social Sciences (SPSS) version 17.0 for Microsoft Windows performed the statistical analyses. 


\section{RES U LTS}

The body and epididymal adipose tissue weights of the obese animals without and with resveratrol supplementation were similar (Figures $1 \mathrm{~A}$ and $1 \mathrm{~B})$, but significantly higher than those of the lean animals. The insulin tolerance test showed that the obese group had lower insulin sensitivity than the lean group $(p<0.05)$. However, resveratrol supplementation increased the insulin tolerance of the supplemented obese group in comparison with the non-supplemented obese group (Figure 1C).

The insulin receptor (Figure 2A), IRS1 (Figure 2B), and Akt (Figure 2C) of the control group given insulin were significantly more phosphorylated than those of the lean group given saline. IR, IRS1 and Akt phosphorylation in the obese group was lower than that in the lean group $(p<0.05)$. However, phosphorylation of these molecules was significantly higher in resveratrol-supplemented obese rats than in non-supplemented obese rats $(p<0.05)$.

The TNF $\alpha$ and NFKB (subunit p65) protein levels and IKK $\alpha$ phosphorylation were analyzed. Obese animals presented a significant increase in TNF $\alpha$ (Figure $3 \mathrm{~A}$ ), IKK $\alpha$ phosphorylation (Figure $3 \mathrm{~B}$ ) and NFKB (Figure 3C) protein levels when compared with lean animals, but supplemented obese rats presented lower values than nonsupplemented obese rats $(p<0.05)$.

\section{DISCUSSION}

Obesity is an important factor in the development of cardiovascular diseases and insulin resistance, and a decisive risk for diabetes Mellitus type $2^{2,3}$. The IKK/NF- $\mathrm{KB}$ inflammatory pathway and TNF $\alpha$ have a critical role in the development of insulin resistance in pathophysiological conditions like obesity ${ }^{14}$. Highfat diet-induced obese rodents presented a significant increase in insulin resistance and expression of inflammatory cytokines, such as IL-1 $\beta, I L-6, T N F \alpha$, and NF- $\kappa B^{13}$. In states such as
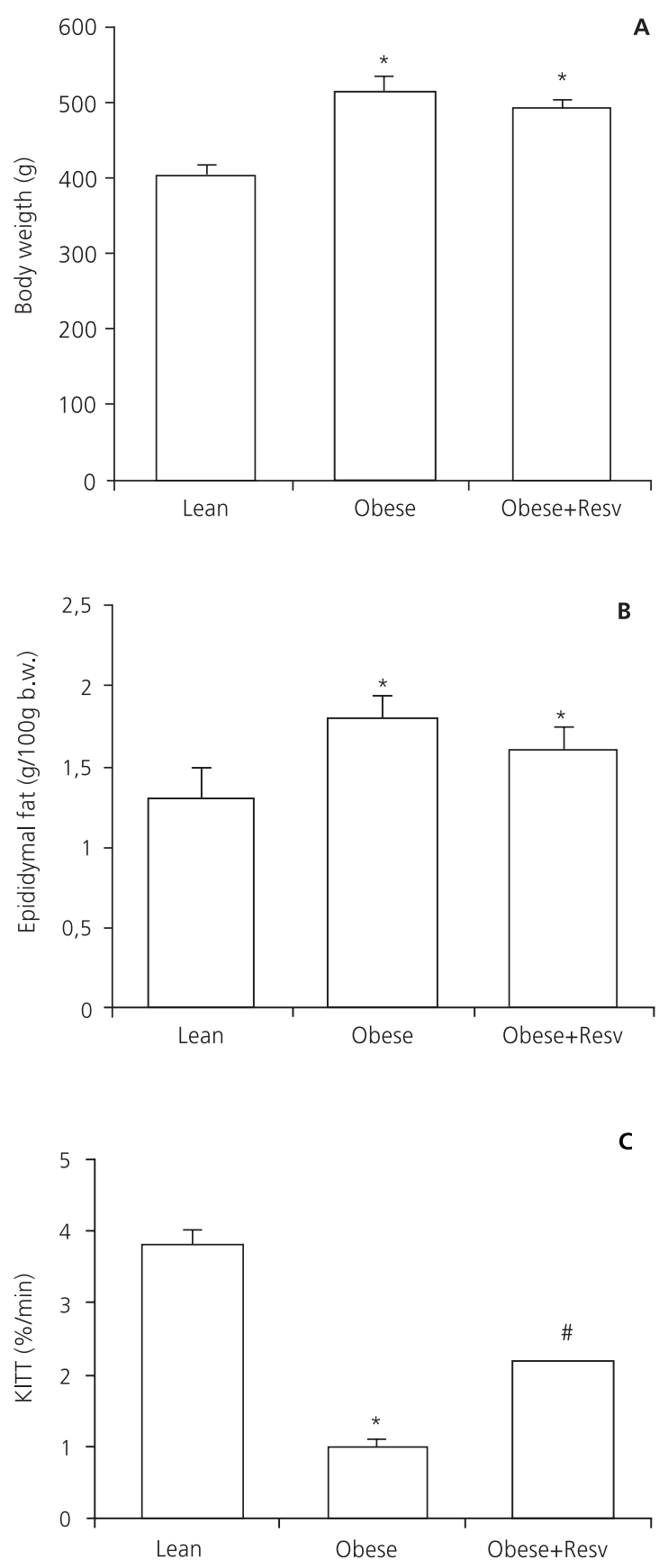

Figure 1. Analysis of body weight and epididymal fat, and rate of glucose disappearance $\left(k_{I T T}\right)$ in the myocardium of lean rats, non-supplemented obese rats, and resveratrol-supplemented obese rats.

Note: Anova: * $p<0.05$ for non-supplemented obese rats and resveratrolsupplemented obese rats versus lean rats; ${ }^{\#} p<0.05$ for resveratrolsupplemented obese rats versus obese rats. Body weight (A), epididymal adipose tissue weight ( $\mathrm{g} / 100 \mathrm{~g}$ body weight) (B) and $\mathrm{k}_{1 \pi T}(\mathrm{C})$. The results were expressed as arbitrary units. Bars represent means \pm Standard Error of the Mean (SEM) of $n=10$ per group.

Source: Universidade do Extremo Sul Catarinense (Unesc). Laboratory of Physiology and Exercise Biochemistry. Criciúma (SC), Brazil, 2013. 

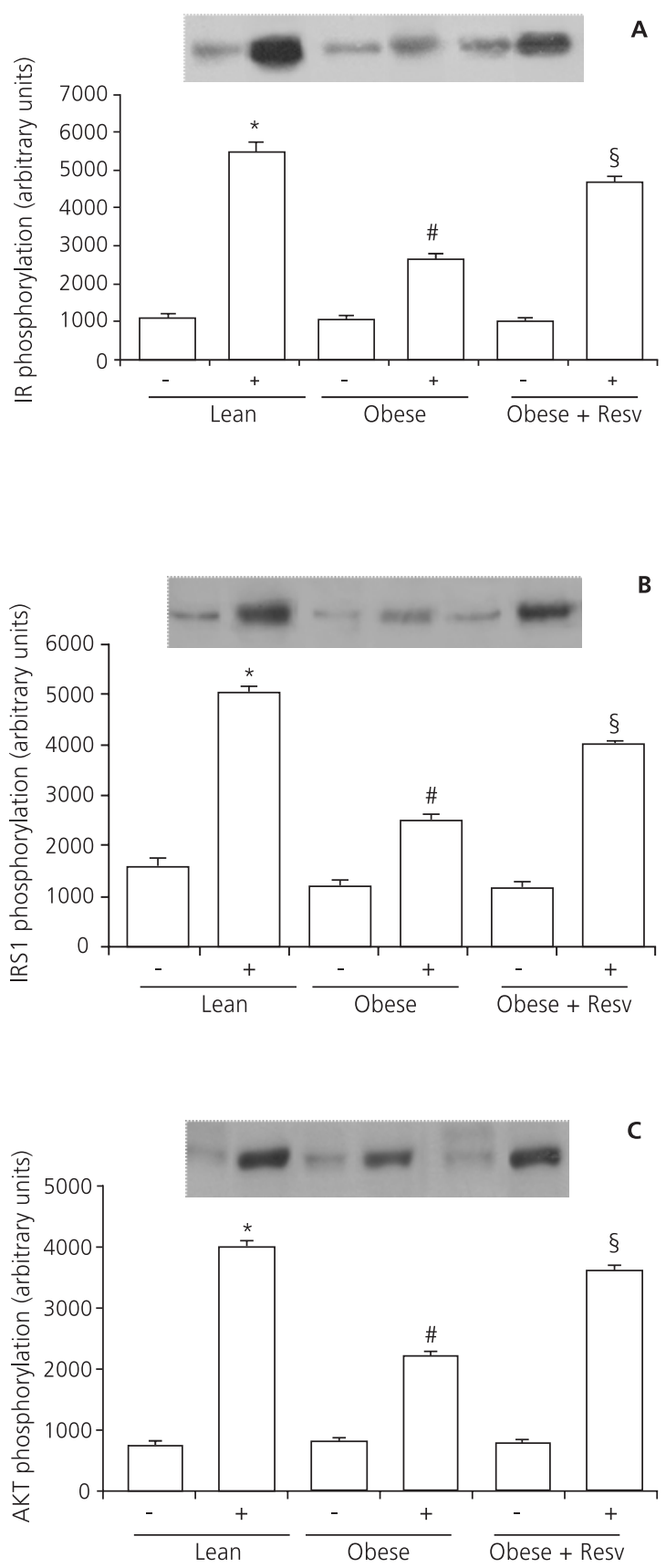

Figure 2. Insulin signaling pathway in the myocardium of lean rats, non-supplemented obese rats, and resveratrolsupplemented obese rats.

Note: Anova: ${ }^{*} p<0.05$ for lean controls with insulin versus lean controls without insulin; $" p<0.05$ for obese rats with insulin versus lean controls with insulin; ${ }^{\S} p<0.05$ for resveratrol-supplemented obese rats with insulin versus non-supplemented obese rats with insulin. IR (A), IRS1 (B), and Akt (C) phosphorylation. The results were expressed as arbitrary units. Bars represent means \pm Standard Error of the Mean (SEM) of $\mathrm{n}=10$ per group.

Source: Universidade do Extremo Sul Catarinense. Laboratory of Physiology and Exercise Biochemistry. Criciúma (SC), Brazil, 2013. insulin resistance, cytokines such as TNF $\alpha$ activate IKK $\alpha$ and IKK $\beta$ by intermediate signaling pathways. This activation promotes the serine phosphorylation of IR and IRS1, reducing insulin signal transduction ${ }^{22}$. However, changes in inflammation levels and myocardial insulin signaling pathway require further investigation. Additionally, nutrients like resveratrol improve insulin sensitivity ${ }^{19,23}$ and reduce inflammation and incidence of coronary diseases ${ }^{16}$. Thus, the study hypothesis was that resveratrol supplementation could benefit the myocardial insulin signaling pathway of obese rats. As expected, obese rats developed insulin resistance and presented higher levels of proinflammatory molecules in the myocardium, and resveratrol supplementation was capable of reversing these findings regardless of body weight and fat loss. Similar results were found in humans where a supplementation of $1 \mathrm{~g} /$ day of resveratrol for 45 days improved insulin sensitivity, fasting glucose, and Homeostatic Model Assessment-Insulin Resistance (HOMA-IR) regardless of body weight ${ }^{24}$.

The resveratrol has also been shown to benefit the insulin signaling pathway ${ }^{21,23}$. Resveratrol supplementation increased IRS1 and Akt phosphorylation in the liver and soleus muscle of insulin-resistant rats, and reduced blood glucose and insulin ${ }^{21}$. The present study found similar results, that is, resveratrol supplementation increased IR, IRS1, and Akt phosphorylation in the myocardium and consequently, insulin sensitivity, as shown by the rate of glucose disappearance. Concordantly, resveratrol supplementation reduced hyperglycemia in an animal obesity model ${ }^{25}$.

Regulation of the insulin pathway by resveratrol can be attributed to its ability to activate the protein Sirtuin 1 (SIRT1) ${ }^{26}$ by inhibiting phosphodiesterase 4 with consequent Adenosine Monophosphate-Activated Protein Kinase (AMPK) activation ${ }^{27}$. SIRT1 activation helps to control glucose homeostasis by various mechanisms, such as regulation of insulin secretion ${ }^{28}$, protection of pancreatic $\beta$-cells ${ }^{29}$, IR modulation (which improves insulin resistance), inflammation 

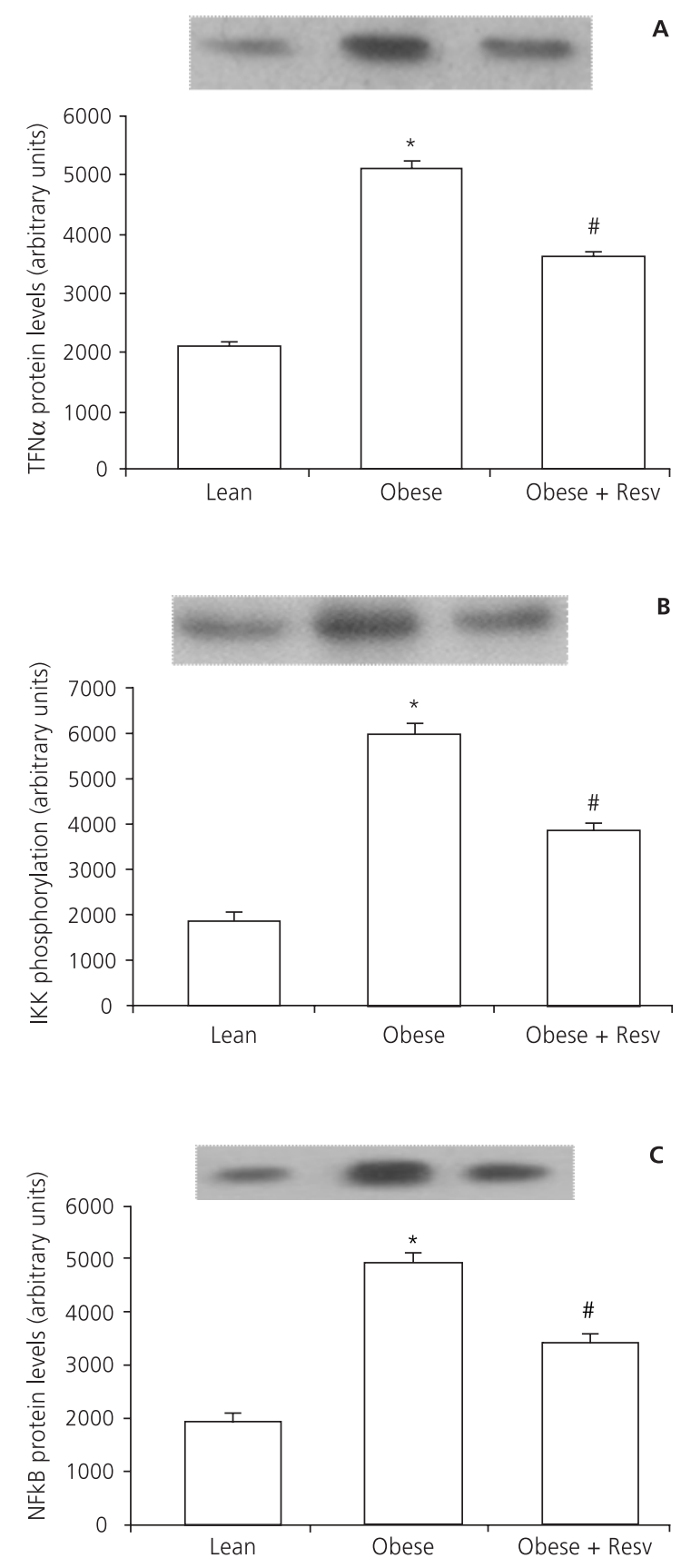

Figure 3. Protein and phosphorylation levels of enzymes involved in the proinflammatory signal transduction in the myocardium of lean rats, non-supplemented obese rats, and resveratrol-supplemented obese rats.

Note: Anova: " $p<0.05$ for obese rats versus lean controls; ${ }^{*} p<0.05$ for resveratrol-supplemented obese rats versus non-supplemented obese rats. TNF $\alpha(A)$ and NFkB(p65) (B) levels and pIKK $\alpha$ (C) phosphorylation. The results were expressed as arbitrary units. Bars represent means \pm Standard Error of the Mean (SEM) of $n=10$ per group.

Source: Universidade do Extremo Sul Catarinense (Unesc). Laboratory of Physiology and Exercise Biochemistry. Criciúma (SC), Brazil, 2013. reduction, lipid mobilization, and adiponectin secretion ${ }^{30}$. The effects of $150 \mathrm{mg} /$ day of resveratrol taken orally by obese men for 30 days were similar to those of calorie restriction, namely better insulin sensitivity and triglyceride levels, and activation of the AMPK/SIRT1 pathway in skeletal muscle ${ }^{31}$.

The biochemical and molecular mechanism by which resveratrol reduces inflammation was not the focus of this study and deserves to be better clarified. However, this study clearly shows the effects of resveratrol on the levels of proinflammatory proteins. Moreover, Gonzales \& Orlando ${ }^{13}$ found that resveratrol acts on the NF-KB of adipocytes by inhibiting IKK, which prevents the translocation of NF- $\mathrm{KB}$ to the nucleus and consequently, reduces the transcription of inflammatory genes ${ }^{13}$. Other studies found that resveratrol reduces IKK phosphorylation in rats' liver ${ }^{32}$ and expression of NF- $K B$ and the cytokines IL-1 $\beta$ and IL- 6 in fibroblasts ${ }^{33}$. In addition to its effect on the insulin pathway, SIRT1 can deacetylate and consequently, inhibit NF- $\mathrm{KB}$, thereby reducing the transcription of proinflammatory genes ${ }^{34}$. SIRT1 activation by resveratrol also reduced the levels of proinflammatory molecules, such as JNK, IKK, and $\mathrm{NF}-\mathrm{KB}^{35}$.

Another explanation for resveratrol's ability to reduce inflammation may lie in its antioxidant nature $^{34}$. Reactive oxygen species activate the molecules that regulate the inflammation pathway, including NF- $\kappa \mathrm{B}$, and promote the secretion of inflammatory mediators ${ }^{36}$. Furthermore, obese individuals have high levels of reactive oxygen species and impaired antioxidant defense system ${ }^{37}$. However, $20 \mathrm{mg} / \mathrm{kg} /$ day of resveratrol were capable of reversing the oxidative stress in the myocardium and aorta of obese rats ${ }^{38}$. Finally, the results are interesting because insulin's effects on the myocardium impacts heart survival ${ }^{39}$. These data evidence that resveratrol can be an effective non-pharmacological treatment to reduce inflammation and consequently, increase whole-body insulin sensitivity. 
Resveratrol treatment increases wholebody insulin sensitivity and the intracellular signaling of this hormone in the myocardium of obese rats, which apparently reduces the levels of proinflammatory cytokines.

\section{ONTRIBUTORS}

TF LUCIANO, SO MARQUES, BLS PIERI and DR SOUZA physiological and molecular analysis and article's drafting. FS LIRA analysis and data interpretation, article's drafting and critical revision of important intellectual content. CT SOUZA conception, design, analysis and data interpretation, article's drafting and critical revision of important intellectual content.

\section{REFERENCES}

1. De Ferranti S, Mozaffarian D. The perfect storm: Obesity, adipocyte dysfunction, and metabolic consequences. Clin Chem. 2008; 54(6):945-55. doi: 10.1373/clinchem.2007.100156

2. Wing RR, Matthews KA, Kuller LH, Meilahn EN, Plantinga $P$. Waist to hip ratio in middle-aged women: Associations with behavioral and psychosocial factors and with changes in cardiovascular risk factors. Arterioscler Thromb. 1991; 11(5):1250-7. doi: 10.1161/01.ATV.11.5.1250

3. Wellman NS, Friedberg B. Causes and consequences of adult obesity: Health, social and economic impacts in the United States. Asia Pac J Clin Nutr. 2002; 11(Suppl 8):S705-9. doi: 10.1046/j.1440-60 47.11.58.6.x

4. Duflou J, Virmani R, Rabin I, Burke A, Farb A, Smialek J. Sudden death as a result of heart disease in morbid obesity. Am Heart J. 1995; 130(2):306-13. doi: 10.1016/0002-8703(95)90445-X

5. Utriainen T, Takala T, Luotolahti M, Rönnemaa T, Laine $\mathrm{H}$, Ruotsalainen $\mathrm{U}$, et al. Insulin resistance characterizes glucose uptake in skeletal muscle but not in the heart in NIDDM. Diabetologia. 1998; 41(5):555-9. doi: 10.1007/s001250050946

6. De Souza CT, Frederico MJ, da Luz G, Cintra DE, Ropelle ER, Pauli JR, et al. Acute exercise reduces hepatic glucose production through inhibition of the Foxo1/HNF-4 $\alpha$ pathway in insulin resistant mice. J Physiol. 2010; 588(pt12):2239-53. doi: 10.1113/ jphysiol.2009.183996

7. Saltiel AR, Kahn CR. Insulin signalling and the regulation of glucose and lipid metabolism. Nature. 2001; 414(6865):799-806. doi: 10.1038/414799a
8. White MF. The IRS-signaling system: A network of docking proteins the mediate insulin action. Mol Cell Biochem. 1998; 182(1-2):3-11. doi: 10.1023/ A:1006806722619

9. Saad MJ, Folli F, Kahn JA, Kahn CR. Modulation of insulin receptor, insulin receptor substrate-1, and phosphatidylinositol 3-kinase in liver and muscle of dexamethasone-treated rats. J Clin Invest. 1993; 92(4):2065-72. doi: 10.1172/JCI116803

10. Shepherd PR, Navé BT, Siddle K. Insulin activates glycogen synthase by a novel PI3-kinase/p70s6k dependent pathway in 3T3-L1 adipocytes. Biochem Soc Trans. 1995; 23(2):202. doi: 10.1042/bst023 202s

11. Datta SR, Brunet A, Greenberg ME. Cellular survival: A play in three Akts. Genes Dev. 1999; 13(22): 2905-27.

12. De Souza CT, Araujo EP, Bordin S, Ashimine R, Zollner RL, Boschero AC, et al. Consumption of a fat-rich diet activates a proinflammatory response and induces insulin resistance in the hypothalamus. Endocrinol. 2005; 146(10):4192-9. doi: 10.1210/ en.2004-1520

13. Gonzales AM, Orlando RA. Curcumin and resveratrol inhibit nuclear factor-kappaB-mediated cytokine expression in adipocytes. Nutr Metab. 2008; 5:17. doi: 10.1186/1743-7075-5-17

14. Luz G, Silva S, Marques S, Luciano TF, De Souza CT. Suplementação de ácidos graxos poli-insaturados ômega-3 e melhora da ação da insulina e da inflamação em fígado de camundongos. Rev Nutr. 2012; 25(5):621-30. doi: 10.1590/\$1415-52732 012000500007

15. Soleas GJ, Diamandis EP, Goldberg DM. The world of resveratrol. Adv Exp Med Biol. 2001; 492(1): 159-82. doi:10.1007/978-1-4615-1283-7_13

16. Robich MP, Osipov RM, Nezafat R, Feng J, Clements RT, Bianchi C, et al. Resveratrol improves myocardial perfusion in a swine model of hypercholesterolemia and chronic myocardial ischemia. Circulation. 2010; 122(Suppl 11):S142-9. doi: 10.1161/ CIRCULATIONAHA.109.920132

17. Olas B, Wachowicz B. Resveratrol, a phenolic antioxidant with effects on blood platelet functions. Platelets. 2005; 16(5):251-60. doi: 10.1080/095 37100400020591

18. Kang W, Hong HJ, Guan J, Kim DG, Yang EJ, Koh $\mathrm{G}$, et al. Resveratrol improves insulin signaling in a tissue-specific manner under insulin-resistant conditions only: In vitro and in vivo experiments in rodents. Metabolism. 2012; 61(3):424-33. doi: 10.1016/j.metabol.2011.08.003

19. Baur JA, Pearson KJ, Price NL, Jamieson HA, Lerin C, Kalra A, et al. Resveratrol improves health and survival of mice on a high-calorie diet. Nature. 2006; 444(7117):337-42. doi: 10.1038/nature05354 
20. Chen S, Li J, Zhang Z, Li W, Sun Y, Zhang Q, et al. Effects of resveratrol on the amelioration of insulin resistance in KKAy mice. Can J Physiol Pharmacol. 2012; 90(2):237-42. doi: 10.1139/y11-123

21. Rocha KK, Souza GA, Ebaid GX, Seiva FR, Cataneo AC, Novelli EL. Resveratrol toxicity: Effects on risk factors for atherosclerosis and hepatic oxidative stress in standard and high-fat diets. Food Chem Toxicol. 2009; 47(6):1362-7. doi: 10.1016/j.fct.20 09.03.010

22. Després JP, Lemieux I. Abdominal obesity and metabolic syndrome. Nature. 2006; 444(7121): 881-7. doi: 10.1038/nature05488

23. Deng J, Hsieh P, Huang J, Lu L, Hung L. Activation of estrogen receptor is crucial for resveratrolstimulating muscular glucose uptake via both insulin-dependent and -independent pathways. Diabetes. 2008; 57(7):1814-23. doi: 10.2337/ db07-1750

24. Movahed A, Nabipour I, Lieben Louis X, Thandapilly SJ, Yu L, Kalantarhormozi M, et al. Antihyperglycemic effects of short term resveratrol supplementation in type 2 diabetic patients. Evid Based Complement Alternat Med. 2013; 2013:851267. doi: 10.1155/20 $13 / 851267$

25. Louis XL, Thandapilly SJ, MohanKumar SK, Yu L, Taylor CG, Zahradka P, et al. Treatment with lowdose resveratrol reverses cardiac impairment in obese prone but not in obese resistant rats. J Nutr Biochem. 2012; 23(9):1163-9. doi: 10.1016/ j.jnutbio.2011.06.010

26. Goh KP, Lee HY, Lau DP, Supaat W, Chan YH, Koh A FY. Effects of resveratrol in patients with type 2 diabetes Mellitus on skeletal muscle SIRT1 expression and energy expenditure. Int J Sport Nutr Exerc Metab. 2013; [Epub ahead of print].

27. Park SJ, Ahmad F, Philp A, Baar K, Williams T, Luo $\mathrm{H}$, et al. Resveratrol ameliorates aging-related metabolic phenotypes by inhibiting CAMP phosphodiesterases. Cell. 2012; 148(3):421-33. doi: 10.1016/j.cell.2012.01.017

28. Bordone L, Motta MC, Picard F, Robinson A, Jhala US, Apfeld J, et al. Sirt1 regulates insulin secretion by repressing UCP2 in pancreatic beta cells. PLoS Biol. 2006; 4(2):31. doi: 10.1371/journal.pbio.00 40031

29. Lee JH, Song MY, Song EK, Kim EK, Moon WS, Han MK, et al. Overexpression of SIRT1 protects pancreatic beta-cells against cytokine toxicity by suppressing the nuclear factor-kappaB signaling pathway. Diabetes. 2009; 58(2):344-51. doi: 10.2337/db07-1795

30. Picard F, Kurtev M, Chung N, Topark-Ngarm A, Senawong $T$, et al. Sirt1 promotes fat mobilization in white adipocytes by repressing PPAR-gamma. Nature. 2004; 429(6993):771-6. doi: 10.1038/ nature02583
31. Timmers S, Konings E, Bilet L, Houtkooper RH, van de Weijer T, Goossens GH, et al. Calorie restrictionlike effects of 30 days of resveratrol supplementation on energy metabolism and metabolic profile in obese humans. Cell Metab. 2011; 14(5):612-22. doi: 10.1016/j.cmet.2011. 10.002

32. Do GM, Jung UJ, Park HJ, Kwon EY, Jeon SM, McGregor RA, et al. Resveratrol ameliorates diabetes-related metabolic changes via activation of AMP-activated protein kinase and its downstream targets in $\mathrm{db} / \mathrm{db}$ mice. Mol Nutr Food Res. 2012; 56(8):1282-91. doi: 10.1002/mnfr. 201200067

33. Csiszar A. Anti-inflammatory effects of resveratrol: possible role in prevention of age-related cardiovascular disease. NY Acad Sci. 2011; 1215: 117-22. doi: 10.1111/j.1749-6632.2010.0 5848.x

34. Zhu X, Liu Q, Wang M, Liang M, Yang X, Xu X, et al. Activation of SIRT1 by resveratrol inhibits TNF-á induced inflammation in fibroblasts. PLoS One. 2011; 6(11):e27081. doi: 10.1371/journal.pone. 0027081

35. Yoshizaki T, Schenk S, Imamura T, Babendure JL, Sonoda N, Bae EJ, et al. SIRT1 inhibits inflammatory pathways in macrophages and modulates insulin sensitivity. Am J Physiol Endocrinol Metab. 2010; 298(3):19-28. doi: 10.1152/ajpendo.00417.2009

36. Ungvari ZI, Orosz Z, Labinskyy N, Rivera A, Xiangmin $\mathrm{Z}$, Smith $\mathrm{KE}$, et al. Increased mitochondrial $\mathrm{H}_{2} \mathrm{O}_{2}$ production promotes endothelial NF-êB activation in aged rat arteries. Am J Physiol Heart Circ Physiol. 2007; 293(1):H37-47. doi: 10.1152/ajpheart.013 46.2006

37. Mohora M, Vîrgolici B, Paveliu F, Lixandru D, Muscurel C, Greabu M. Free radical activity in obese patients with type 2 diabetes Mellitus. Rom J Intern Med. 2006; 44(1):69-78.

38. Avila PR, Marques SO, Luciano TF, Vitto MF, Engelmann J, Souza DR, et al. Resveratrol and fish oil reduce catecholamine-induced mortality in obese rats: Role of oxidative stress in the myocardium and aorta. Br J Nutr. 2013; 110(9):1580-90. doi: 10.1017/S000711451300092

39. Gao F, Gao E, Yue TL, Ohlstein EH, Lopez BL, Christopher TA, et al. Nitric oxide mediates the antiapoptotic effect of insulin in myocardial ischemia-reperfusion: The roles of PI3-kinase, Akt, and endothelial nitric oxide synthase phosphorylation. Circulation. 2002; 105(12):1497-502. doi: 10.11 61/01.CIR.0000012529.00367.0F

Received on: 6/24/2013 Final version on: $11 / 28 / 2013$ Approved on: 1/22/2014 
